\title{
Penanaman Modal Sebagai Penggerak Penguatan Hukum Dan Pembangunan Ekonomi
}

\author{
Muhammad Fadhilah \\ Magister Hukum Ekonomi, Universitas Indonesia \\ Email :medfadhil1602@gmail.com
}

\begin{abstract}
Abstrak. Ketika kita membahas indonesia adalah negara kepulauan yang sangat kaya dan berlimpah hasil alamnya, maka turut pula mengkaji tugas-tugas administrasi pemerintahan dan negara, baik secara aturan hukum tertulis dalam konstitusi atau aturan yang terkumpul di hukum konstitusi untuk mengelola secara efektif Sumber Daya Alam yang Indonesia punya. Mengingat Indonesia merupakan negara hukum, maka Hukum Administrasi Negara (HAN) dan Hukum Investasi sangat dibutuhkan sebagai instrumen untuk memantau penggunaan kekuasaan pemerintahan. Kajian ini mengakomodir dua permasalahan, yaitu batasan definitif dari peraturan perundang-undangan tentang hukum Investasi, kebijakan, dan keputusan menurut HAN dan asas-asas dan norma-norma HAN dalam pembuatan peraturan perundang-undangan, peraturan kebijakan, dan keputusan. Penelitian ini dilakukan dengan pendekatan hukum normatif atau studi pustaka hukum. Hasil studi ini menyatakan bahwa Peraturan adalah hukum yang in abstracto atau general norm yang sifatnya mengikat umum (berlaku umum) dan tugasnya adalah mengatur hal-hal yang bersifat umum (general). Sementara Peraturan kebijakan hanya berfungsi sebagai bagian dari operasional penyelenggaraan tugas-tugas pemerintahan, karenanya tidak dapat mengubah ataupun menyimpangi peraturan perundang-undangan.
\end{abstract}

Kata Kunci : Hukum Administrasi negara, Hukum Investasi, Ekonomi Pembangunan

Abstract. When we discuss that Indonesia is an archipelagic country that is very rich and examines its natural products, it also examines the tasks of the government and the state, both in terms of written legal rules in the constitution or rules collected in constitutional law to effectively carry out Indonesia's natural resources. have. Considering that Indonesia is a state based on law, the State Administration Law (HAN) and Investment Law are needed as instruments for implementing governmental power. This study accommodates two problems, namely the definitive limits of Investment regulations, policies and decisions according to HAN and the principles and norms of HAN in making regulations, policy regulations, and decisions. This research was conducted with a normative legal approach or legal literature study. The results of this study state that a regulation is a law that is abstract or general norm which is generally binding (generally accepted) and its task is to regulate general matters. While policy regulations only function as part of the operational tasks of government, they cannot change or deviate from statutory regulations.

Keywords: State Administration Law, Investment Law, Economics Development

\section{PENDAHULUAN}

Indonesia sebagai negara hukum dengan tujuan mencapai kesejahteraan masyarakatnya membutuhkan suatu hukum yang digunakan oleh pemerintah untuk mengatur masyarakat tersebut agar tercipta suatu kesejahteraan yang dikehendaki. Berdasarkan ketentuan Pasal 1 ayat
(3) UUD negara Republik Indonesia Tahun 1945, "Negara Indonesia adalah Negara hukum". Indonesia sebagai negara hukum, setiap penyelenggaraan urusan pemerintahan haruslah berdasarkan pada hukum yang berlaku (wetmatigheid van bestuur). 
Laporan World Food Programme menyebutkan bahwa satu dari setiap sembilan penduduk bumi, yaitu 805 juta orang, kekurangan makanan untuk hidup yang sehat dan aktif. Dengan pertumbuhan populasi yang diekspektasikan menjadi lebih dari 9 miliar orang dalam 30 tahun ke depan, jumlah produksi makanan harus ditingkatkan lagi sebesar 70 persen. Kalau tidak, masyarakat dunia akan semakin kelaparan lagi. Tantangan ini muncul di tengah pembahan iklim. Temperatur meningkat dan air minum menjadi sumber daya yang semakin langka (70 persen air bersih di dunia digunakan untuk agrikultur).

Agrikultura yang presisi menjanjikan akan mengumpulkan dan mengevaluasi kekayaan data real time Berdasarkan faktorfaktor seperti cuaca, air, level nitrogen, kualitas udara, dan penyakit. Semua faktor ini tidak spesifik untuk masing-masing pertanian atau lahan per hektare, melainkan spesifik ke setiap inci persegi lahan tersebut. Lahan pertanian akan dipagari barisan sensor yang memberikan puluhan bentuk data ke cloud. Data tersebut akan dikombinasikan dengan data dari GPS dan pola cuaca. Setelah informasi terkumpul dan dievaluasi, algoritme akan menghasilkan serangkaian instruksi bagi pelani tentang apa yang harus mereka lakukan, kapan, dan di mana.

Hal tersebut diatas merupakan contoh dari salah satu dari banyaknya pekerjaan rumah yang harus dilakukan oleh bangsa ini. Sebagai contoh lainnya adalah pengelolaan sumber daya berupa tambang yang harus benar-benar kita harus kelola dengan baik. Supaya pengelolaan sumber daya alam kita berjalan dengan baik tentunya memerlukan seperangkat aturan yang baik, termasuk penanaman modalnya. Aturan penanaman modal juga sangat penting untuk diperhatikan agar cita-cita bangsa kita dalam penguasaan sumber daya yang ada di negara kita manfaatnya dirasakan bagi segenap bangsa indonesia. Sehingga pembangunan ekonomi indonesia dapat berjalan dengan baik.

Untuk mengkaji permasalahan tersebut digunakan metode penelitian melalui pendekatan analisis data bersifat normatif kualitatif (bertitik tolak dari perundang-undang, tidak menggunakan rumus statistik), serta teknik pengumpulan data melalui studi kepustakaan untuk mengkaji bahan hukum primer (perundang-undangan), bahan hukum sekunder (pendapat para ahli), dan bahan hukum tersier (internet) yang bertujuan untuk mendapatkan informasi langsung berkenaan Jurnal Hukum ini.

Dari uraian diatas muncul beberapa permasalahan yang dapat dirumuskan, yaitu:

1. Bagaimana konsep peraturan perundangundangan Indonesia untuk mengakomodir suatu kebijakan atau keputusan terkait dengan penanaman modal ?

2. Bagaimana seharusnya kebijakan terkait dengan penanaman modal sebagai penggerak penguatan hukum dan ekonomi pembangunan?

\section{METODE PENELITIAN}

Metode pendekatan yang digunakan dalam penelitian ini adalah metode pendekatan yuridis normatif. Penelitian hukum normatif adalah penelitian hukum kepustakaan. Penelitian hukum normatif disebut juga sebagai penelitian doktrinal dengan studi terhadap buku - buku, literatur - literatur, dan sumber hukum Penanaman Modal.

Jenis data yang digunakan dalam penelitian ini adalah data sekunder yaitu data yang berasal dari studi kepustakaan, baik literatur hukum, peraturan perundang-undangan, maupun bahan-bahan kepustakaan terkait. Untuk menganalisis data dan menarik kesimpulan dari hasil penelitian, kedua bahan hukum yaitu bahan hukum primer dan sekunder dianalisis dengan metode kualitatif untuk selanjutnya disajikan dalam bentuk deskriptif analitis.

\section{HASIL DAN PEMBAHASAN}

\section{Konsep Peraturan Perundangan- undangan Indonesia}

Menurut Pasal 1 angka 2 UU No. 10

Tahun 2004 Tentang Pembentukan Peraturan 
Jurnal Ilmu Sosial dan Pendidikan

http://ejournal.mandalanursa.org/index.php/JISIP/index

Terakreditasi Peringkat 5 (No. SK: 85/M/KPT/2020)

Perundang-undangan, yang dimaksud dengan peraturan perundang-undangan adalah peraturan tertulis yang dibentuk oleh lembaga negara atau pejabat yang berwenang dan mengikat secara umum. Peraturan perundang-undangan yang bersifat mengikat umum (algemeen verbindend voorschrift) disebut juga dengan istilah undangundang dalam arti materiil (wet in materiele zin), yaitu ieder rechtsvoorschrift van de overheid met algemeen strekking (semua hukum tertulis dari pemerintah yang mengikat umum). Berdasarkan kualifikasi norma hukum di atas peraturan perundang-undangan itu bersifat umum-abstrak. Perkataan bersifat umumabstrak dicirikan oleh unsur-unsur sebagai berikut.

Merujuk pada rumusan tujuan negara yang tercantum dalam alenia keempat Pembukaan UUD 1945 khususnya pada redaksi "memajukan kesejahteraan umum", ada yang berpendapat bahwa Indonesia menganut paham negara kesejahteraan (welfare state), seperti Azhary dan Hamid S. Attamimi. Menurut Hamid S. Attamimi, bahwa negara Indonesia memang sejak didirikan bertekad menetapkan dirinya sebagai negara yang berdasar atas hukum, sebagai rechtsstaat. Bahkan rechtsstaat Indonesia itu ialah rechtsstaat yang memajukan kesejahteraan umum, mencerdaskan kehidupan bangsa, dan mewujudkan suatu keadilan sosial bagi seluruh rakyat Indonesia.

Negara hukum materil merupakan pengertian Negara hukum dalam arti luas, yang sering di sebut dengan Negara hukum modern (modern rechtsstaat). Pada tipe Negara hukum materil, lingkup tugas pemerintah bukan saja melaksanakan ketentuan undang-undang semata, melainkan juga turut membuat undangundang atau berbagai peraturan pelaksanaannya. Negara tidak hanya bertugas sebagai penjaga malam, melainkan berkewajiban pula secara aktif untuk terlibat dalam berbagai bidang kehidupan masyarakat demi tercapainya tujuan bernegara.

Gagasan ini muncul pada akhir abad-19 yang menjadi pelopor negara hukum modern,
Vol. 5. No. 2 Maret 2021

p-ISSN: 2598-9944 e- ISSN: 2656-6753 yaitu Prof. Kranenburg yang terkenal dengan istilah "welfare state" atau Negara kesejahteraan. Teori ini dikenal dengan negara hukum material, karena adanya pandangan yang menyatakan bahwa negara selain bertugas membina ketertiban hukum juga ikut bertanggung jawab dalam membina dan mewujudkan kesejahteraan bagi rakyatnya. Gagasan bahwa pemerintah dilarang campur tangan dalam urusan warga Negara, baik di bidang sosial maupun bidang ekonomi, sebagaimana yang telah di kemukakan oleh konsep legal state telah bergeser kearah gagasan baru, bahwa pemerintah harus bertanggung jawab atas kesejahteraan rakyat. Pemerintah tidak boleh bersifat pasif atau berlaku sebagai penjaga malam semata melainkan harus terlibat aktif dalam melaksanakan upaya-upaya untuk membangun kesejahteraan masyarakat dengan cara mengatur kehidupan ekonomi dan sosial.

Gagasan baru ini, mencakup dimensi ekonomi dengan sistem yang dapat menguasai kekuatan-kekuatan ekonomi dan dapat memperkecil perbedaan sosial dan ekonomi, terutama dalam mengatasi ketidak merataan distribusi kekayaan di kalangan rakyat. Gagasan inilah yang selanjutnya melahirkan konsep negara hukum welfare state (Negara kesejahteraan).

Tipe utama Negara hukum kesejahteraan adalah adanya kewajiban pemerintah untuk melakukan bestuuruzorg atau service publik yakni penyelenggaraan kepentingan umum. Dapat pula dirumuskan sebagai kewenangan yang sah bagi pemerintah untuk turut campur dalam kegiatan sosial guna melaksanakan tugastugas menyelenggarakan kesejahteraan umum.

Mengacu pada teori negara kesejahteraan (welfare state, verzorgingsstaat), tugas pemerintah tidak hanya terbatas untuk melaksanakan undang-undang yang telah telah dibuat oleh lembaga legislatif. Menurut perspektif welfare state, pemerintah dibebani kewajiban untuk menyelenggarakan kepentingan umum (bestuurszorg) atau mengupayakan kesejahteraan sosial, yang dalam 
Jurnal Ilmu Sosial dan Pendidikan

http://ejournal.mandalanursa.org/index.php/JISIP/index

Terakreditasi Peringkat 5 (No. SK: 85/M/KPT/2020)

menyelenggarakan kewajiban itu pemerintah diberi kewenangan untuk campur tangan (staatsbemoeienis) dalam kehidupan masyarakat, dalam batas-batas yang diperkenankan oleh hukum. Bersamaan dengan campur tangan tersebut, pemerintah juga diberi kewenangan untuk membuat dan menggunakan peraturan perundang-undangan. Arti lain, pemerintah memiliki kewenangan dalam bidang legislasi.

Dalam menyelenggarakan kesejahteraan rakyat sesuai pergeseran liberal rechtstaat menjadi sociale rechstaat (de haan cs) menyebabkan pemerintah atau penguasa harus proaktif mencampuri bidang kehidupan rakyatnya. Dengan timbulnya perubahan pola kehidupan masyarakat dari masyarakat agraris menjadi masyarakat industrialis, banyak timbul masalah yang tidak mungkin ditanggulangi oleh masyarakat sendiri. Masalah-masalah kehidupan yang berkaitan dengan memperoleh nafkah yang layak menimbulkan masalah-masalah di bidang ketengakerjaan, pendidikan, keselamatan kerja, kesehatan, lingkungan dan seterusnya berakibat campur tangan pemerintah di bidang kependudukan, pengelolaan kesejahteraan. Semuanya menyebabkan pemerintah harus proaktif mengatur perencanaan (planning), pengorganisasian, pelaksanaan atau penerapan kebijakan-kebijakan pemerintah demi kesejahteraan rakyat pada umumnya. Semua hal itu menyebabkan semakin banyaknya hukum yang mengatur hubungan antar pemerintah dan masyarakat yang dapat dipergunakan sebagai dasar hukum bagi tindakan penguasa.

Pemberian kewenangan legislasi kepada pemerintah itu semakin mendesak sejak berkembangnya ajaran negara kesejahteraan, yang memberikan kewajiban kepada pemerintah untuk memberikan pelayanan sosial dan mewujudkan kesejahteraan umum, yang untuk menopang peranan ini pemerintah dilekati dengan kewenangan legislasi. Artinya tidak mungkin meniadakan kewenangan legislasi bagi pemerintah.Menurut Penjelasan Pasal 1 angka 2 UU No. 5 Tahun 1986 tentang Peradilan Tata
Vol. 5. No. 2 Maret 2021

p-ISSN: 2598-9944 e- ISSN: 2656-6753

Usaha Negara, peraturan perundang-undangan adalah semua peraturan yang bersifat mengikat secara umum yang dikeluarkan oleh Badan Perwakilan Rakyat bersama pemerintah, baik di tingkat pusat maupun di tingkat daerah yang juga mengikat secara umum. Rumusan pengertian peraturan perundang-undangan seperti demikian ini mencakup pengertian materiil dan formil. Maka dari itu, Berdasarkan rumusan penjelasan Pasal 1 angka 2, UU No. 5 Tahun 1986 tersebut, dapat disimpulkan bahwa keputusan dari badan atau pejabat tata usaha negara seperti peraturan dari Badan Koordniasi Penanaman Modal misalnya, merupakan pengaturan yang bersifat umum (besluit van algemene strekking) dan termasuk peraturan perundang-undangan (algemeen verbindende voorschriften).

\section{Kebijakan Terkait Dengan Penanaman Modal dan hubungannya dengan Pembangunan Ekonomi}

Menurut Dornbusch dan Fischer Dalam pengertian umum, investasi diartikan sebagai pembelian (dan berarti juga produksi), baik terhadap aktiva fisik seperti membangun rel kereta api, membangun pabrik, pembukaan lahan, dan lain sebagainya, maupun aktiva finansial (keuangan) seperti membeli sekuritas atau bentuk keuangan lainnya atau aktiva kertas. Sebagai contoh, seseorang yang membeli saham atau obligasi. Namun dalam ekonomi makro pengertian investasi lebih dipersempit yakni sebagai pengeluaran masyarakat yang ditujukan untuk menambah stok modal fisik. Dalam perhitungan pendapatan nasional dan statistik, pengertian investasi adalah seluruh nilai pembelian para pengusaha atas barang-barang modal dan pembelanjaan untuk mendirikan industri dan pertambahan dalam nilai stok barang perusahaan yang berupa bahan mentah, bahan belum diproses, dan barang jadi.

Investasi sangat dibutuhkan untuk memacu perekonomian yang pada akhirnya dapat mengatasi berbagai permasalahan di daerah, baik dibidang ekonomi maupun sosial. Dinamika investasi sangat mempengaruhi tinggi 
rendahnya pertumbuhan ekonomi. Sehingga dapat menciptakan lapangan kerja dan mengatasi pengangguran. Salah satu sebab utama dari lambatnya pemulihan ekonomi sejak krisis 1997, yaitu buruknya kinerja investasi akibat sejumlah permasalahan yang mengganggu pada setiap tahapan penyelenggaraannya. Keadaan tersebut menyebabkan lesunya kegairahan melakukan investasi, baik untuk perluasan usaha yang telah ada maupun untuk investasi baru. Masalah ini akan sangat berpengaruh pada pertumbuhan perekonomian yang selama ini lebih didorong oleh pertumbuhan konsumsi ketimbang investasi atau ekspor.

Dalam investasi tercakup dua tujuan utama, yakni untuk mengganti bagian dari penyediaan modal yang rusak (depresiasi) dan tambahan penyediaan modal yang ada (investasi neto). Sedangkan tujuan lainnya menyebutkan bahwa pengeluaran investasi adalah pembelian barang-barang yang memberi harapan menghasilkan keuntungan di masa mendatang. Artinya, pertimbangan yang diambil oleh perusahaan dalam memutuskan membeli atau tidak barang dan jasa tersebut adalah harapan dari perusahaan akan kemungkinan keuntungan yang bisa diperoleh (dengan dijual atau digunakan untuk proses produksi). Harapan keuntungan ini merupakan faktor utama dalam keputusan investasi.

Investasi dapat dibedakan menjadi tiga komponen, yaitu pertama, investasi tetap dunia usaha (business fixed investment), yaitu pengeluaran yang ditujukan untuk pembangunan pabrik atau bangunan baru, pembelian peralatan produksi dan mesinmesin baru. Kedua, investasi tempat tinggal (residential investment) yang sebagian besar berupa investasi perumahan. Ketiga, investasi persediaan (inventory investment) yaitu pengeluaran yang ditujukan untuk menambah stok persediaan.

Adapun motif suatu perusahaan menanamkan modalnya ke Indonesia adalah mencari keuntungan. Keutungan tersebut diperoleh dari berbagai factor: upah buruh yang murah, dekat dengan sumber bahan mentah, luasnya pasar yang baru, menjual teknologi (merek, paten, rahasia dagang, design industri), menjual bahan baku untuk dijadikan barang jadi, insentif untuk investor, dan status khusus Negara-negara tertentu dalam perdagangan internasional.

Nilai Investasi yang tinggi akan memberikan dampak yang besar terhadap perekonomian bangsa dan sebaliknya jika investasi rendah maka akan menghambat pembangunan dan implikasinya adalah jumlah pengangguran secara otomatis juga akan meningkat. Namun dalam perkembangannya perekonomian Indonesia menekankan kepada pertumbuhan ekonomi yang tinggi dan ternyata memang masih terjadi rentan pada kemampuannya menetralisir efek negatif dari globalisasi dan gejolak pasar internasional. Ketidaksiapan Indonesia dengan tidak berperannya sistem hukum, politik dan sosial yang dapat menyikapi berbagai kesempatan dari keterbukaan ekonomi ini, semuanya ini sangat berperan dalam menciptakan prestasi semu dari pembangunan Nasional.

Untuk mencapai pertumbuhan ekonomi yang tinggi, diperlukan adanya peningkatan nilai penanaman modal yang positif bagi kelangsungan pelaku usaha karena sumber pembentukan modal yang paling efektif adalah tabungan domestik, namun pembentukan modal domestik di Indonesia masih rendah, sehingga masih diperlukan peranan ekspor dan investasi asing. Investasi yang lazim disebut dengan istilah penanaman modal atau pembentukan modal merupakan salah satu komponen yang mempengaruhi tingkat pengeluaran agregat. Pengeluaran dalam perekonomian terdiri dari pengeluaran rumah tangga, investasi oleh perusahaan, dan pengeluaran ekspor-impor. Dengan demikian naik turunnya tingkat kegiatan ekonomi ditentukan oleh perubahan masingmasing faktor atau gabungan dari faktor-faktor tersebut. Namun masing-masing faktor mempunyai pengaruh yang berbeda didalam mempengaruhi fluktuasi ekonomi yang berlaku dari waktu ke waktu. 
Di dalam Undang-undang Republik Indonesia Nomor 25 Tahun 2007 tentang Penanaman Modal Pasal 1 angka 1 menyatakan bahwa yang dimaksud dengan Penanaman modal adalah segala bentuk kegiatan menanam modal, baik oleh penanam modal dalam negeri maupun penanam modal asing untuk melakukan usaha di wilayah negara Republik Indonesia. Sementara itu pada angka 2 dan 3 penanaman odal terbagi menjadi 2 yaitu penaman modal dalam negeri dan penaman modal asing. Penanaman modal dalam negeri adalah kegiatan menanam modal untuk melakukan usaha di wilayah negara Republik Indonesia yang dilakukan oleh penanam modal dalam negeri dengan menggunakan modal dalam negeri. Sedangkan Penanaman modal asing adalah kegiatan menanam modal untuk melakukan usaha di wilayah negara Republik Indonesia yang dilakukan oleh penanam modal asing, baik yang menggunakan modal asing sepenuhnya maupun yang berpatungan dengan penanam modal dalam negeri.

Terkait dengan kebijakannya pemerintah berdasarkan Pasal 4 Ayat 2 memberi perlakuan yang sama bagi penanam modal dalam negeri dan penanam modal asing dengan tetap memperhatikan kepentingan nasional, menjamin kepastian hukum, kepastian berusaha, dan keamanan berusaha bagi penanam modal sejak proses pengurusan perizinan sampai dengan berakhirnya kegiatan penanaman modal sesuai dengan ketentuan peraturan perundangundangan, dan membuka kesempatan bagi perkembangan dan memberikan perlindungan kepada usaha mikro, kecil, menengah, dan koperasi.

Dalam pasal 7 ayat 1 Undang-undang Nomor 25 Tahun 2007 menyatakan Pemerintah tidak akan melakukan tindakan nasionalisasi atau pengambilalihan hak kepemilikan penanaman modal, kecuali dengan undangundang. Jaminan ini memberi kepastian hukum kepada penanam modal atas kelangsungan, keberadaan usaha di Indonesia.

Jurnal Ilmu Sosial dan Pendidikan
Selain itu, penanaman modal juga harus didukung oleh kualitas infrastruktur yang memadai. Yang dimaksud dengan infrastruktur adalah berbagai instalasi dan kemudahan dasar terutama dalam sistem transportasi, komunikasi dan listrik) yang diperlukan oleh masyarakat dalam melakukan aktivitas usaha baik untuk industri maupun untuk perdagangan dan kelancaran pergerakan orang, barang, dan jasa dari suatu daerah ke daerah lain atau ke negara lain. Faktor infrastruktur fisik dibagi menjadi dua, yakni ketersediaan infrastruktur dan kualitas serta akses infrastruktur. Ketersediaan infrastruktur fisik adalah untuk kelancaran kegiatan usaha yang perlu didukung oleh ketersediaan infrastruktur fisik seperti jalan raya, kereta api, pelabuhan laut dan udara, sarana komunikasi seperti telepon dan pos serta sumber energi seperti listrik. Sedangkan kualitas dan akses terhadap infrastruktur fisik adalah kualitas infrastruktur harus dalam keadaan baik. Infrastruktur fisik yang tersedia belum tentu menjamin kelancaran usaha bila infrastruktur yang tersedia berada dalam kondisi yang tidak baik. Kualitas infrastruktur selain memperlihatkan kondisi fisiknya yang siap dan layak untuk digunakan, juga ditunjukkan dengan kemudahan akses terhadap infrastruktur yang ada.

Infrastruktur yang baik akan meningkatkan produktivitas dan menurunkan biaya produksi. Jadi, infrastruktur juga merupakan faktor yang ikut mendorong terciptanya iklim investasi yang kondusif. Keadaan jalan yang baik, tersedianya pelabuhan yang memadai, tersedianya sumber energi yang dibutuhkan oleh perusahaan, tersedianya transportasi, telekomunikasi akan membantu meningkatkan kegiatan investasi. Untuk memenuhi kebutuhan infrastruktur tesebut maka pengeluaran pemerintah (pusat atau daerah) sangat menentukan untuk membiayai peningkatan dan perbaikan infrastruktur. Sehingga Kebutuhan tambahan modal diperlukan Indonesia untuk menutupi kemampuan Angararan Pendapatan Belanja 
Jurnal Ilmu Sosial dan Pendidikan

http://ejournal.mandalanursa.org/index.php/JISIP/index

Terakreditasi Peringkat 5 (No. SK: 85/M/KPT/2020)

Negara (APBN) yang sangat kecil terpenuhi Untuk mengolah sumber alam yang melimpah, Indonesia memerlukan modal yang besar.

Berbicara mengenai hubungan penanaman modal dengan pembangunan ekonomi, maka perlu dijelaskan pengertian pembangunan yang dimaksud. Pembangunan adalah kata yang digunakan dalam semua media massa di seluruh dunia dan merupakan konsep yang sering kali disebut dan dibahas oleh semua lapisan masyarakat, baik di Timur maupun di Barat, Terutama di kalangan politisi, wartawan, dan ilmuwan sosial. Pengertian pembangunan perlu dihayati sebelum seseorang dapat memahami keseluruhan proses dan teori pembangunan. Usaha untuk memahami konsep pembangunan itu sendiri jauh lebih sulit daripada memahami proses dan teori pembangunan. Namun demikian, ada beberapa pengertian yang biasanya disinonimkan dengan konsep pembangunan, yaitu konsep pertumbuhan ekonomi, modernisasi, industrialisasi, normative atau hak kebutuhan dasar, dan environmentalisme.

Pengertian konsep pembangunan yang paling mudah dan popular ialah kemakmuran ekonomi. Kemakmuran ekonomi dengan taraf kehidupan yang lebih baik, terutamanya dari segi modal dan kekayaan sebuah negara. Negara yang kaya-raya dianggap sebagai negara yang makmur. Kemakmuran ekonomi sebuah negara dinilai dari segi pertumbuhan ekonomi yang dicapai oleh negara tersebut dari masa ke masa.

Terdapat tiga elemen penting yang berkaitan dengan pembangunan ekonomi. Pertama, Pembangunan sebagai suatu proses. Pembangunan sebagai suatu proses, artinya bahwa pembangunan merupakan suatu tahap yang harus dijalani oleh setiap masyarakat atau bangsa. Sebagai contoh, manusia mulai lahir, tidak langsung menjadi dewasa, terapi untuk menjadi dewasa harus melalui tahapan-tahapan pemimbuhan. Demikian pula, setiap bangsa harus menjalani tahap-tahap perkembangan untuk menuju kondisi yang adil, makmur, dan sejahtera.
Vol. 5. No. 2 Maret 2021

p-ISSN: 2598-9944 e- ISSN: 2656-6753
Kedua, Pembangunan sebagai suatu usaha untuk meningkatkan pendapatan per kapita. Sebagai suatu usaha, pembangunan merupakan tindakan aktif yang harus dilakukan oleh suatu negara dalam rangka meningkatkan pendapatan per kapita. Dengan demikian, sangat dibutuhkan peran serta masyarakat, pemerintah, dan semua elemen yang terdapat dalam suatu negara untuk berpartisipasi aktif dalam proses pembangunan. Hal ini dilakukan karena kenaikan pendapatan per kapita mencerminkan perbaikan dalam kesejahteraan masyarakat.

Ketiga, Peningkatan pendapatan per kapita harus berlangsung dalam jangka panjang. Suatu perekonomian dapat dinyatakan dalam keadaan berkembang apabila pendapatan per kapita dalam jangka panjang cenderung meningkat. Hal ini tidak berarti bahwa pendapatan per kapita harus mengalami kenaikan terus-menerus. Misalnya, suatu negara tenadi musibah bencana alam ataupun kekacauan politik, maka mengakibatkan perekonomian negara tersebut mengalami kemunduran. Namun, kondisi tersebut hanyalah bersifat sementara yang terpenting bagi negara tersebut kegiatan ekonominya secara rata-rata meningkat dari tahun ke tahun.

Dengan terpenuhinya tambahan modal untuk mengolah sumber alam yang melimpah, maka Investasi dalam peralatan modal tidak saja meningkatkan produksi tetapi juga kesempatan kerja. Dengan terbukanya kesempatan kerja yang lebih luas, maka tingkat pendapatan masyarakat bertambah dan berbagai macam kebutuhan rakyat terpenuhi. Dengan demikian kenaikan laju investasi akan meningkatkan pendapatan nasional sehingga dapat memberikan instrumen maupun perlengkapan bagi aparat dan penegak hukum lainnya. Oleh sebab itu investasi merupakan jalan keluar utama dari masalah yang dihadapi negara dan merupakan kunci utama menuju penguatan hukum dan pembangunan ekonomi. 


\section{KESIMPULAN}

Indonesia adalah negara yang berdasar atas hukum, sebagai rechtsstaat. Bahkan rechtsstaat Indonesia itu ialah rechtsstaat yang memajukan kesejahteraan umum, mencerdaskan kehidupan bangsa, dan mewujudkan suatu keadilan sosial bagi seluruh rakyat Indonesia. Maka tugas pemerintah tidak hanya terbatas untuk melaksanakan undang-undang yang telah telah dibuat oleh lembaga legislatif. Menurut perspektif welfare state, pemerintah dibebani kewajiban untuk menyelenggarakan kepentingan umum (bestuurszorg) atau mengupayakan kesejahteraan sosial, yang dalam menyelenggarakan kewajiban itu pemerintah diberi kewenangan untuk campur tangan (staatsbemoeienis) dalam kehidupan masyarakat, dalam batas-batas yang diperkenankan oleh hukum, salah satunya adalah menangani masalah penanaman modal untuk meningkatkan nilai investasi.

Nilai Investasi yang tinggi akan memberikan dampak yang besar terhadap perekonomian bangsa dan sebaliknya jika investasi rendah maka akan menghambat pembangunan dan implikasinya adalah jumlah pengangguran secara otomatis juga akan meningkat. penanaman modal juga harus didukung oleh kualitas infrastruktur yang memadai. Infrastruktur yang baik akan meningkatkan produktivitas dan menurunkan biaya produksi. Jadi, infrastruktur juga merupakan faktor yang ikut mendorong terciptanya iklim investasi yang kondusif. Dengan demikian kenaikan laju investasi akan meningkatkan pendapatan nasional sehingga dapat memberikan instrumen maupun perlengkapan bagi aparat dan penegak hukum lainnya dan merupakan kunci utama menuju penguatan hukum dan pembangunan ekonomi.

\section{Saran}

1) Pemerintah Harus berusaha menghilangkan Budaya Hukum Korupsi. Indonesia merupakan negara dengan tingkat korupsi tinggi. Banyak penelitian menunjukkan bahwa Indonesia merupakan tempat yang subur tumbuhnya budaya korupsi. Dari penelitian yang dilakukuan oleh lembaga pemerhati korupsi internasional menempatkan Indonesia sebagai negara terkorup di kawasan asia pasifik. Masalah kebijakan hukum korupsi tidak akan terlepas dengan kekuasaan ekonomi dan politik suatu negara sehingga stigma korupsi dapat menjadi simbol elastis mengakarnya korupsi ketatanegaraan sebagai korupsi sistemik atau korupsi kelembagaan. Pejabat negara yang telah memiliki gaji besar tetap melakukan korupsi. Pola hidup mewah yang berkembang dalam masyarakat memberi motivasi bagi pejabat melakukan korupsi. Tindakan korupsi telah menjadi budaya dalam birokrasi di Indonesia. dilakukan dengan terus terang, sistematis, dan terorganisasi. Tidak ada budaya malu dari pejabat negara. Pejabat negara mempunyai anggapan bahwa korupsi yang dilakukan merupakan tindakan yang secara umum dapat dipahami masyarakat Indonesia. Karena dengan korupsi ini tingkat kepercayaan investor yang ingin berinvestasi menjadi berkurang, khawatir modalnya sebagai orang atau badan usaha tidak dapat untung maupun kembali. Untuk mencegah terjadinya tidak pidana korupsi yang lebih luas adalah dengan cara salah satunya adalah kampanye anti korupsi dan penegakkan hukum yang kuat berupa peningkatan hukuman bagi para pelaku korupsi.

2) Jangan Terlalu terlena dengan Penanaman Modal Asing. Indonesia memang saat ini untuk mengelola sumber daya alamnya yang melimpah masih terus membutuhkan modal yang tidak sedikit. Sebagai alternatif harus mencari penanaman modal atau investasi dari luar demi mendapatkan pemasukan negara untuk mengelola sumber daya alamnya. Namun dalam hal ini penulis mengingatkan agar pemerintah tidak terlalu lama membiarkan kekayaan alam dikelola oleh asing lewat penanaman modal asing tersebut, karena selain mengganggu 
kedaulatan hukum, juga mengganggu kedaulatan ekonomi yang mana jika kita kelola sendiri keuntungan bagi negara akan meningkat.

\section{DAFTAR PUSTAKA}

\section{Buku}

Alec Ross, 2019, Industri-Industri Masa Depan (Diterjemahkan dari The Industries of The Future) Jakarta, Rene Turos Indonesia

Amir A, 2009, Perekonomian Indonesia, FE. UNJA. Jambi

Dumairy, 1996, Perekonomian Indonesia, Erlangga, Jakarta

Erman Radjagukguk, 2006, Hukum Investasi Di Indonesia, Universitas indonesia Fakultas Hukum, Jakarta,

Marbun, Moh. Mahfud MD, 1987, Pokok-Pokok Hukum Administrasi Negara, Penerbit Liberty, Yogyakarta

Ridwan HR, 2011, Hukum Administrasi Negara, Rajawali Press Jakarta

Windhu Putra, 2019, Perekonomian Indonesia (Penerapan beberapa Teori Ekonomi Pembangunan di Indonesia, Rajawali Pers, Depok

Tesis

Didi Latip, 2009, “Analisa Pengaruh Penanaman Modal Asing Langsung (FDI) Terhadap Pertumbuhan Ekonomi Regional Propinsi Tahun 2000-2006 ". Tesis. Universitas Indonesia

\section{Peraturan Perundang-undangan}

Undang Undang Nomor 5 Tahun 1986 tentang Peradilan Tata Usaha Negara

Undang Undang Nomor 10 Tahun 2004 Tentang Pembentukan Peraturan Perundangundangan

Undang Undang Nomor 25 tahun 2007 Tentang Penanaman Modal 